\title{
THE IMPROVEMENT OF ORGANIZATIONAL CITIZENSHIP BEHAVIOURS (OCB) THROUGH ISLAMIC WORK ETHIC, AFFECTIVE COMMITMENT, AND THE IDENTITY OF THE ORGANIZATION
}

\author{
Gunadi Wibowo ${ }^{1 *}$, Wuryanti $2^{*}$
}

* Affiliation:
1,2 Bank Mandiri,
Semarang, Indonesia

\begin{abstract}
:
Employee who are willing to voluntarily help fellow co-workers to do work outside the assigned job description and the assistance provided is not included in the performance assessment, called organizational citizenship behavior (OCB). Podsakoff et.al (2000) states that OCB can influence organizational effectiveness because it can help improve co-workers productivity, increase managerial productivity and streamline the use of organizational resources for productive purposes. This research was conducted to identify the effect of Islamic work ethics, affective commitment and organizational identity on OCB. The data were collected from 110 employees at the Muhammadiyah Islamic Hospital of Kendal and the Muhammadiyah Darul Istiqomah Hospital of Kendal. The data were later analyzed using Structural Equation Modeling (SEM) using the Analysis of Moment Structure (AMOS 24) software. The result indicate that affective commitment and organizational identity have a significant effect on OCB while Islamic work ethics have no significant effect on OCB. The researcher hopes that this research can be developed in future research by adding other variables related to OCB that may have a greater influence on OCB.

Keywords: OCB, Islamic work ethics, affective commitment, organizational identity
\end{abstract}

\section{INTRODUCTION}

Nowadays a very sharp competition going on in the business world. Many things can trigger the condition becomes a factor, among others, namely the effects of globalization, the development of science and technology that rapidly. To cope with these conditions, organizations that want to maintain the sustainability of its business or maintain its growth will increasingly depend on how your organization manages the human resources (HR) has to obtain excellence in competing. 
For the community, the hospital founded by the Islamic community organization later called the Islamic hospitals into something uplifting and boast of while hoping that the Islamic hospital has superior human resources and can implement the work ethics of Islam in every area of Ministry. Ali and Al-Owaihan (2008) States that Islam gives a special perspective on "work" and the manifestation of the concept of a work ethic that is special about the work ethic of Islam (Islamic work ethics).

With the practice of the Islamic work ethic, is expected to improve the behavior of OCB among HR. OCB short of organizational citizenship behaviors is the behavior of someone who is working with volunteer help and do jobs that are not contained in the description of the tasks assigned to him. Podsakoff et.al (2000) States that the OCB can increase the effectiveness of the Organization as it can help in increasing the productivity of co-workers, increased productivity and streamline managerial use of organizational resources to things that are productive.

Some previous research indicates linkages work ethics of Islam against the OCB. Fakhar et.al (2012) conducts research on HR government hospitals and banks in Pakistan. The results of the research show that there are positive and significant influence on work ethics of Islam against the OCB. Alhyasat (2012) in her research found a high level of commitment most HR in the Jordan Press Foundation toward Islamic work ethic. There is a significant influence on several dimensions of work ethics of Islam against the OCB as for most other Islamic work ethic dimensions do not affect significantly to OCB.

In addition, to facilitate achieving the objectives of the Organization, the management of human resources by the organizations need to pay attention to the commitment of human resources. In addition to having good working behavior and quality of human resources must be committed to the organization. The commitment of the Organization is classified into three types, namely the commitment of affective, normative, and continuance. Of the three, the most helpful and effective commitment for the company due to human resources with high affective commitment tends to feel confident against the company so will try to optimally to improve the quality of his work for the sake of the achievement of the objectives of the Organization (Kusumastuti and Nurtjahjanti, 2013).

Results of research Nizam et.al (2016) against 156 respondents from several smallmedium enterprise (SME) textile traffickers in Selangor, Kuala Lumpur and Johor (Malaysia) proved that the application of the Islamic high work ethic will produce commitments high organizational and shows that the application of Islamic work ethic can help manifest the commitment to the organization. Research et.al Nizam (2016) also showed a significant and positive relationship between the work ethics of Islam with the affective commitment. Research results Subejo et.al (2013) towards HR firefighter in the Provincial Government of Jakarta shows that organizational commitment effect significantly to OCB.

The identity of the Organization (organizational identity) is basically a reflection of the image of the Organization, is a reflection of the culture of the Organization and enhance the effectiveness of the organization functioning in adjusting to the demands of the environment ( Hatch and Schultz, 2004 in Himam, 2012). The identity of the Organization will create the motivation needed to evoke a sense of volunteerism misbehave in organizations (Joon and Himam, 2013). 
Research results Fakhar et.al (2012) suggested that subsequent research can be done on a private sector company and can add another variable to be examined. It is exciting to researchers conducting research of the influence of work ethics of Islam against the OCB.

Researchers are also interested in researching the influence of Islamic work ethic toward

affective commitment that is part of the commitment of the organization. The researchers chose the affective commitment because as an important factor that determines the loyalty and dedication of HUMAN RESOURCES as delivered by Rhoades et.al (2001). Researchers will also examine the influence of organizational identity and affective commitment against OCB.

There are several medical facilities in the Regency of Kendal Central Java province which was founded and owned by civic organizations. In the meantime, there is two Islamic hospital which is quite widely known by people in Kendal and the surrounding area, namely the Islamic Muhammadiyah Hospital (RSI) Kendal and General Hospital Muhammadiyah Darul Istiqomah (RSDI) Kendal. Both hospitals were relatively identical since it was founded and owned by Persyarikatan Muhammadiyah.

Satisfaction survey by the Quality Management Representative (QMR) RSI committed against the patient's inpatient space in January 2018 shows that $9 \%$ of patients felt dissatisfied with the condition of the bathroom/toilet and 5.9\% did not feel satisfied with the condition of the space waiting for patients. While the survey in February 2018 shows that $8.1 \%$ of patients felt dissatisfied with the condition of the bathroom/toilet and 5.2\% are not satisfied with the condition of the patient's waiting room. Rodhiyatun et.al (2014) delivered the results of the satisfaction survey in September 2013 by QMR RSI against the patient's inpatient space shows that $55 \%$ of patients are satisfied, $11.5 \%$ quite satisfied but there are $15 \%$ of patients stated less satisfied, four out of ten respondents of whom complained about the everyday interactions of the Environment Ministry of the hospitalization, also found two complaints about interpersonal health workers towards patients and there were three complaints about nursing services towards patients.

It illustrates there is still dissatisfaction from patients despite the observations and information from the public, RSI has been the choice of the community not only residents but also the citizens of Kendal Regency Kabupaten Batang. For the community, RSI and RSDI has a good reputation as well as having its own peculiarities related to the application of Islamic work ethic in the activities of his Ministry.

From the explanation above, researchers interested in examining the level of commitment of the RSI and RSDI against work ethics of Islam and the influence of the application of the work ethic, affective commitment to the Islamic identity of the Organization and the OCB. Researchers will also examine the influence of organizational identity and affective commitment against the OCB. Therefore this study entitled enhancement of OCBmelalui work ethic, affective commitment, and the identity of the Organization.

\section{LITERATURE REVIEW Islamic Work Ethics}

Work ethic is defined as a collection of values, nature, attitudes, and behavior about how someone is doing the job or the responsibility. Islam strongly demanded that the believer has 
strong moral values and follow the teachings of Islam in running his job to seek the pleasure of Allah SWT, which is the ultimate goal in life (Abdi et.al, 2014 dalam Zahrah et.al, 2016).

Ahmad and Owoyemi (2012) define Islamic work ethic is a set value or belief system sourced from the Qur'an and the Sunnah regarding work. According to Ali and Al-Owaihan (2008), the work ethics of Islam is the orientation of that direct and influence the engagement and participation of Muslims in the world of work. In the workplace, Muslims are expected to know what is right and what is wrong based on the teachings of Islam and to behave and act in accordance with the teachings of Islam (Zahrah et.al, 2016).

Some of the definitions above it can be concluded that the work ethic of Islam is a set value or belief system based on the Qur'an and the Sunnah of the Prophet Muhammad are held by members of the organization that animates every thought, Word and acts or behavior it works.

Alhyasat (2012) mentions that there are nine Islamic work ethic dimension i.e. proficiency,

kindness and forgiveness in dealing with employees, advice to Muslims and creativity in services, sense of responsibility, fairness and justice. integrity, teamwork, obedience, observing dignity and honor of the profession.

\section{Affective Commitment}

According to Allen and Meyer (1990) in Hidayat (2010), organizational commitment can be distinguished into three types, each commitment has a different level or degree. These three types of organizational commitment are:

1. Continuance commitment is a commitment on the basis of the perception of the members about the losses that would be received if the membership of the organization or out of profits that would have accrued if it maintains its membership so the commitment remained in the organization based on considerations of profit and loss.

2. Normative commitment is a commitment which includes feelings of members regarding the obligations and responsibilities that must be given to the Organization so that members remain in the organization because it feels obliged to loyal to organizations.

3. Affective commitment relating to emotional, identification and involvement of members in the Organization so as to have an emotional attachment to organizations that are seen in the engagement and feeling happy and enjoy his role in the organization.

The affective commitment of the Organization's efforts to make human resources have a strong conviction to follow all the values of the Organization (Kartika, 2011 in Han, 2012). Affective commitment becomes an important factor that determines the loyalty and dedication of human resources. human resources with high affective commitment tends to show a sense of having a top organization, experience increased participation in the activities of the Organization, the desire to achieve the objectives of the Organization, and the desire to remain a member of the Organization (Rhoades et.al, 2001).

Boon et.al (2006) dalam Kusumastuti dan Nurtjahjanti (2013) stated that the affective commitment rated higher than normative commitments and continuesly, while the normative 
commitment rated higher than rational commitment so that human resources are committed would be more affective value to the organization because it involves emotional factors which will then work with the feeling of being happy and enjoying her role in the organization.

Of some of the definitions above it can be concluded that the affective commitment is a strong desire to remain a member of an organization by attachment emotionally which is reflected through the feeling of pleasure, engagement, enjoying the role of an acceptance of the values and objectives of the organization.

The indicators used in the research based on affective commitment variable used Rhoades et.al (2001) is as follows:

1. Have deep meaning privately.

2. Having high sense of belonging to an organization.

3. Proud to inform about the Organization to others..

4. Happy if can work in the organization until retirement.

5. Feel that problems faced by the organization are his problem as well.

There are a few antecedents of affective commitment that has identified among other personal characteristics, structural characteristics, the characteristics associated with the work, and work experience, which had work experience the strongest and most consistent (Meyer et.al, 1993 in Han et.al, 2012).

$290 / 5000$

Results of research Nizam et.al (2016) against 156 respondents from several small medium enterprises (SMEs) in Selangor, Kuala Lumpur and Johor (Malaysia) proves that the work ethic of the Islamic has a significant and positive influence towards affective commitment, so the hypothesis proposed is:

H1 : Work ethics of Islam influential significantly to affective commitment.

\section{Organization Identity}

The identity of the organization is primarily a reflection of the image of the Organization, is a reflection of the culture of the Organization and enhance the effectiveness of the organization functioning in adjusting to the demands of the environment (Hatch and Schultz, 2004 in Himam, 2012). The identity of the organization similar to the self-image of the organization which are defined as the characteristics of the Organization, the characteristics "central, enduring, and distinctive" (Gioia et.al, 2004 in Himam, 2012).

The identity of the organization developed as an understanding with the Member organization toward the characteristic or characteristic of an organization that has important properties, relatively permanent, and can be used as a differentiator with another organization. This common understanding emerged as an interpretation against the values that developed in the Organization and is the result of a process of social reconstruction as a result of the process of social interaction (Hatch and Schultz, 2004; Dhalla, 2007 in Himam, 2012).

Some of the definitions above can be concluded that the identity of the organization is a reflection of the image and culture of the organization that emerged as an interpretation against the values that developed in the Organization and is the result of the process of 
reconstruction social as a result of the process of social interaction member organizations as well as the function increases the effectiveness of the Organization in adjusting to the demands of the environment.

Balmer, Stuart and Greyser (2009) in Prasetyo and Himam (2013) menjelaskan identitas Balmer, Stuart and Greyser (2009) in Joon and Himam (2013) describes the Organization's identity as a unity from six aspects in the Organization, namely: (1) actual identity is a special attribute that belongs to the Organization at the time of This can be seen for example in the business segment, objectives of the Organization, ethos and style of work as well as segments of the market; (2) identity is communicated the message conveyed by the Organization through communication to outside parties either through the logo, advertising and public relation; (3) identity conceived with regard to the description and organization reputation on customers' mind and other stakeholders; (4) covenanted identity associated with the basic message implied in the name and logo or organization; (5) the ideal identity related to identity or positioning the expected ideal organization; (6) the desired identity related to the desire of the owners and a leader against the Organization in the long run.

The link between work ethics of Islam with the identity of the organization can be viewed from the understanding that the work ethics of Islam is a set value or belief system based on the Qur'an and the Sunnah of the Prophet Muhammad are held by members of the Organization Animates every thought, Word and action or behavior works.

The values are then developed as the Organization's identity as a collective understanding of the members of the Organization against which the organization is important to its characteristics, is relatively permanent, as well as the nature of the difference between one organization with the other organizations (Hatch and Schultz, 2004; Dhalla, 2007 in Himam, 2012). So the hypothesis proposed is :

$\mathrm{H} 2$ : Work ethics of Islam influential significantly to the identity of the Organization.

\section{Organizational Citizenship Behaviours (OCB)}

Work ethics of Islam influential significantly to the identity of the Organization (Barnard, 1938 in Harper, 2015). OCB is defined as discretionary, not allow the formal reward rewards and can improve the effectiveness of the Organization's functions. The free and voluntary nature because such behavior is not required by the role or the requirements description clearly specified tasks based on agreements with the Organization but rather as individual options (Organ, 1988 in Podsakoff et.al, 2000).

Allameh et.al (2012) mentions four characteristics of OCB:

1. Activities conducted is not specified work activities.

2. The activities because of personal motivation.

3. This behavior not defined formally as well as noted clearly in a formal recognition system.

4. Perilaku ini membantu keseluruhan organisasi tetapi tidak dievaluasi dalam sistem efektivitas. 
Based on the above description it can be drawn the conclusion that the OCB is individual behavior outside of the job description, as well as not specified formally in the recognition system/rewards, are carried out voluntarily and contribute increased effectiveness and efficiency in the Organization.

Podsakoff et.al (2000) reveals seven dimensions of OCB :

1. Helping Behavior. A Behavior that like helping others voluntarily and attitude are always alert in anticipation against problems that may arise with regard to employment.

2. Sportsmanship. The ability to tolerate treatment less well than their peers with no complaints and keep a positive attitude shows, or even willing to sacrifice personal desires for the good of the Organization.

3. Organizational Loyalty. Promote the Organization to outside parties, protect and defend your organization from threats from outside and committed to the Organization despite the unfavorable conditions.

4. Organizational Compliance. The acceptance of the individual will be the Organization's rules and policies are realized with adherence to the rules and the policy even if no one is watching.

5. Individual Initiative. Individuals have more initiative, for example, someone will ask if not understand his work, or working on his work without having to wait for earlier ruled.

6. Civic Virtue. Great interest or commitment to the Organization as a whole, indicated by the desire to participate actively in the governance of the Organization (e.g., following the meetings, participated in the discussion of policies, delivered a the idea), pay attention to environmental conditions to know the threats and opportunities for the Organization, and is always looking for opportunities to do good (e.g. reporting a fire hazard or suspicious activities).

7. Self Development. Voluntarily undertake actions in order to increase the selfdevelopment abilities, skills, and knowledge.

Liu et.al, (2005) in Abbasi amd Rana (2012) stated that the OCB improves the performance of individuals and organizations. The cultural component of the OCB organizationspecific in nature and relies on the values, beliefs and work ethic of the organization.

conducts research on HR 165 at 15 government hospitals and 8 private bank in Pakistan, found that the work ethic of Islam has a positive influence and significantly to the OCB and both variables have a strong relationship Thus it can be concluded that the higher work ethics of Islam will be the higher the OCB. So the hypothesis proposed is:

H3 : Work ethics of Islam influence significantly to OCB.

Findings from Subejo et.al (2013) toward 355 HR firefighters in the Jakarta provincial Government show that the third dimension or type of organizational commitment effect significantly to OCB so hypothesis put forward is: H4: affective Commitment of significant effect against the OCB. 
Prasetyo and Himam (2013) argues that the identity of the Organization will create the motivation needed to evoke a sense of volunteerism misbehave in the Organization.

Amini et. al (2016) do research on HR tax office in Lorestan Province, Iran with the size of the sample as much as 250 respondents. The results of the research show that the identity of the Organization has an impact on the proposed hypotheses so that OCB is:

H5: the identity of the influential organization significantly to OCB.

\section{Empirical Model}

The empirical model of this research is as follows:

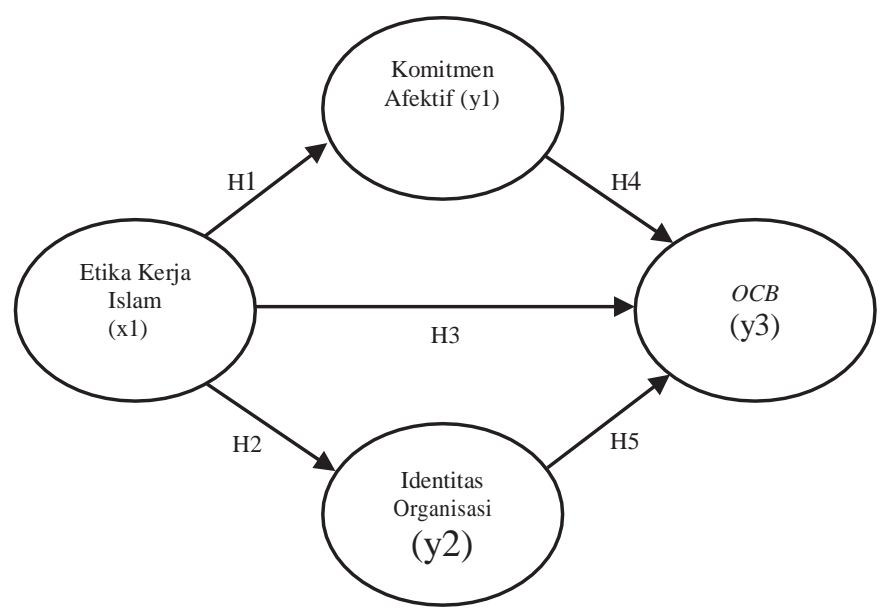

Figure 1

Research Empirical Model

\section{RESEARCH METHOD}

\section{Population and Sample}

The population in this research is all RSI HR, which totaled 459 people and all RSDI HR totaled 145 people, so the amount of the population is 604 people. Sampling used in this study i.e. proportional random sampling (Malhotra, 1999 in Wahyudi, 2012) because it involves multiple subgroups. Ghozali (2017:62) recommended that the sample size is between 100 to 200 should be used for the estimation of the Maximum Likelihood Estimation method (ML). In this research are disseminated 130 questionnaires $(22 \%$ of the total population), i.e. 100 questionnaires in RSI (22\% of the total HR RSI) and 30 questionnaires in the RSDI ( $21 \%$ of the total TBS RSDI). Of 100 questionnaires presented on RSI, accumulated 84 questionnaire (84\%). While from a questionnaire distributed in 30 RSDI, collected 26 questionnaires (87\%). The answer from the 110 respondents (85\%) These can be analyzed.

\section{Collecting Data Method}

The collecting data method in this research are :

1. Observation

Observation or direct observation is intended to obtain a clear picture of the situation and the activities performed by HR RSDI and RSDI. 
2. Dissemination of the Questionnaire

The data collection method is directly done by submitting a list of questions on the respondent. Kuesionerdiserahkan directly on the respondents and returned to the researchers within 7 days after the submission of the questionnaire.

\section{operational definitions of variables and Indicators}

Islam adalah seperangkat the value of work ethic or belief system based on the Qur'an and the Sunnah of the Prophet about the work that animates every thought, Word and work behaviour of human resources. Indicator variable work ethics of Islam in this study cited six of the nine dimensions of work ethics of Islam according to the Alhyasat (2012), namely expertise, friendliness, responsibility, fairness, and cooperation.

Affective commitment or attitude is the desire to remain in the organization because of the congruency of values and emotional attachment. Affective commitment variable indicators used in this study cited five of the six indicators of affective commitment conveyed Rhoades et.al (2001) very meaningful organization, sense of belonging, pride, emotional attachment, and loyal.

The identity of the organization is a reflection of the Organization's image in the minds of human resources to differentiate with other organizations. The indicator variable is quoted three of the six aspects of the identity of the organization that submitted by Balmer, Stuart, and Greyser (2009) in Joon and Himam (2013) IE organization-specific attributes, external communications, and organizational reputation.

OCB is a voluntary behavior that is not included in the formal duties and contributes to the increased effectiveness and efficiency in the organization. Variable OCB indicators used in this study cited six of the seven dimensions of OCB expressed by Podsakoff et.al (2000) that is helpful, the attitude of sportsmanship, loyalty, obedience, initiative and responsiveness.

To test the model and hypothesis in this study used the SEM analysis (Structural Equation Modelling) using program Analysis of Moment Structure (AMOS 24).

\section{RESULT}

\section{Confirmatory Factor Analysis (CFA)}

Confirmatory factor analysis aims to measure the extent to which the strong structure of the dimensions that make up a factor or in other words the analysis aims to confirm whether the indicator variables used are confirming a factor. 


\section{Confirmatory factor analysis konstruk eksogen etika kerja Islam}

The results of the processing of confirmatory factor analysis for invalid constructs work ethics of Islam can be seen in Figure 2.

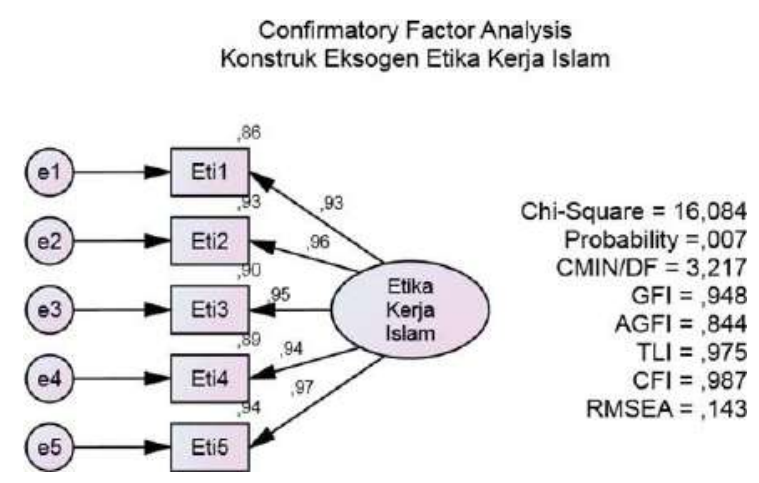

FIGURE 2

The CFA model invalid constructs a variable has a value of Indikatordari Exogenous coefficient $\lambda$ or component estimate significantly (p $0.05 \leq$ ) when the value of the critical ratio $(\mathrm{CR})>2.0$ (Ferdinand, 2005). Based on the text output of AMOS on the regression weight known that the estimate using component of each indicator variable work ethic on Islam is $21.903 ; 25.055 ; 24.977 ; 21.621$ thus a match (suitability) between dimensions invalid constructs with latent variables, in other words, there is a conformity between the model filed with the data used.

\section{Confirmatory factor analysis konstruk endogen komitmen afektif, identitas organisasi dan OCB}

he results of the processing of confirmatory factor analysis for invalid constructs identity, affective organizational commitment and OCB can be seen in Figure 3 .

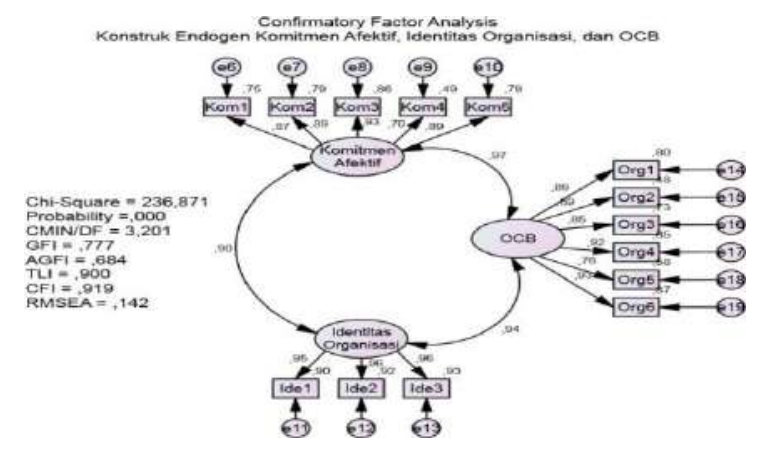

FIGURE 3

CFA Model Endogen Construct

The indicator variable has a value of the coefficient component or $\lambda$ estimates significantly ( $p 0.05 \leq$ ) when the value of the critical ratio $(\mathrm{CR})>2.0$ (Ferdinand, 2005). Based on the text output of AMOS on the regression weight known that the estimate using component for each indicator on the variables endogen is $12.233 ; 14.207 ; 8.419 ; 12.297 ; 8.829 ; 12.929 ; 16.114$; 
$10.251 ; 17.019$. Thus a match (suitability) between dimensions invalid constructs with latent variables, in other words, there is a conformity between the model filed with the data used.

\section{Estimation Of Structural Equation Models}

After the model is analyzed using confirmatory factor analysis and be proved thateach indicator can define latent invalid constructs, then a full model of the SEM can be analyzed. The result of processing by using AMOS can be seen in Figure 4.

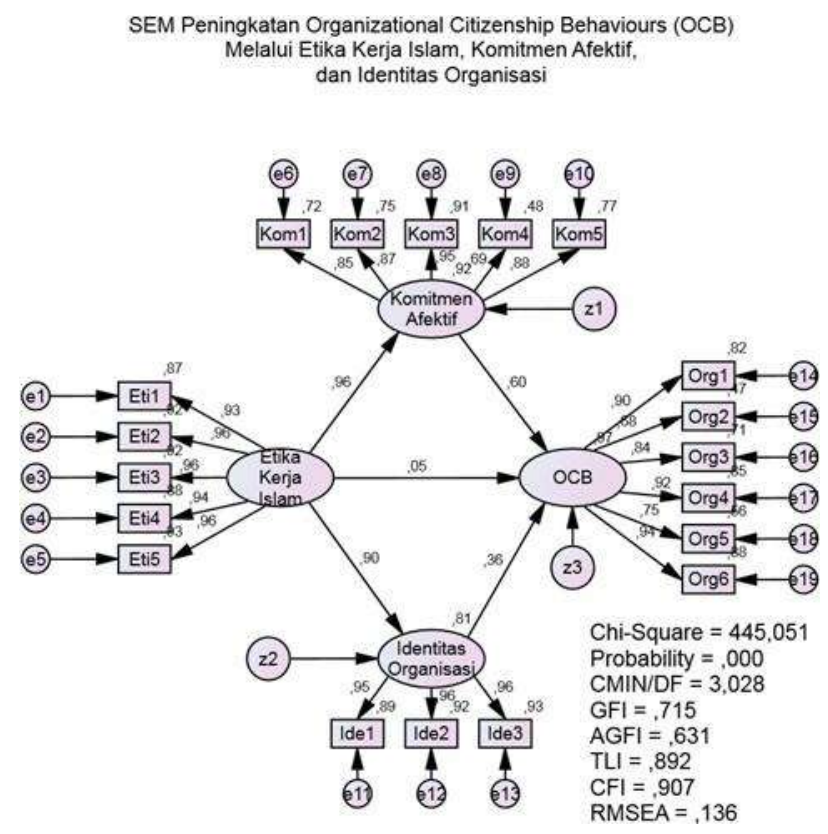

FIGURE 4

Structural Full Model

\section{The suitability and statistical tests}

Based on the index of conformity and cut-off value that is used to test whether a model is accepted or rejected as presented by Ferdinand (2005) as a whole is seen in the following table 1:

Tablr 1

Goodness-Of-Fit Index)

\begin{tabular}{|l|c|c|c|}
\hline \multicolumn{1}{|c|}{ Goodness of Fit Index } & Cut-of-Value & $\begin{array}{c}\text { Hasil } \\
\text { Analisis }\end{array}$ & $\begin{array}{c}\text { Evaluasi } \\
\text { Model }\end{array}$ \\
\hline X $^{2}$ Chi-Square & Diharapkan kecil & 445,051 & \\
\hline Significance Probability & $\geq 0,05$ & 0,000 & Marginal \\
\hline RMSEA & $\leq 0,08$ & 0,136 & Marginal \\
\hline GFI & $\geq 0,90$ & 0,715 & Marginal \\
\hline AGFI & $\geq 0,90$ & 0,631 & Marginal \\
CMIN/DF & $\leq 2,00$ & 3,028 & Marginal \\
TLI & $\geq 0,95$ & 0,892 & Marginal \\
CFI & $\geq 0,95$ & 0,907 & Marginal \\
\hline
\end{tabular}

Source : Processed Primary Data, 2018 


\section{Validity Test}

A convergent validity shows the dimensions of the indicator are significant when the indicator variable coefficient was greater than twice the standard error (Anderson and Gerbing in Ferdinand, 2005:304).

Based on the text output of AMOS on the regression weight shows that all indicators generate value estimation critical ratio greater than two times the standard error, then it can be inferred that the indicator variables used is valid. This indicates that it is a valid indicator measure what should be measured in the model presented.

\section{Reliability Test}

Basically, a test of reliability shows the extent to which a measurement tool can provide results that are relatively the same when performed measurement of return on the same subject. The approach recommended in the reliability test is assessing the magnitude of composite reliability and variance extracted from each invalid constructs (Ferdinand, 2005:93).

\section{Composite (Construct) Reliability}

The value of reliability in order to construct the variable work ethic, affective commitment, organizational identity, and OCB was $0.979 ; 0.929 ; 0.969 ; 0.936$. Unknown reliability value $\geq 0.70$ for the entire variable so that data is worth to use.

2. Variance Extracted

The value of the variance extracted sequentially for variable work ethic, affective commitment, organizational identity, and OCB is $0.901 ; 0.725 ; 0.913 ; 0.713$. Unknown variance value extracted $\geq 0.50$ for all variable so it can be stated that this data is worth to use.

\section{Hypothesis Testing}

Testing the hypothesis has been put forward is done by looking at the value of CR in the regression weights at text output AMOS. When the critical ratio (CR) of the estimate or coefficient $\geq 2$ then it can be inferred that the resulting regression coefficients are significant (Ferdinand, 2005:37).

Overall acceptance and rejection of the hypothesis are presented in the following table 2:

Table 2

Acceptance and rejection of the hypothesis

\begin{tabular}{|l|c|c|c|}
\hline \multicolumn{1}{|c|}{ Hypothesis } & C.R. & Siginificance & Conclusion \\
\hline $\begin{array}{l}\text { Work ethics of Islam influential significantly to } \\
\text { affective commitment }\end{array}$ & 13,730 & Significant & Accepted \\
\hline $\begin{array}{l}\text { Work ethics of Islam influential significantly to the } \\
\text { identity of the Organization }\end{array}$ & 16,240 & Significant & Accepted \\
\hline Etika kerja Islam influential significantly to OCB & 0,311 & $\begin{array}{c}\text { Not } \\
\text { Significant }\end{array}$ & Rejected \\
\hline Affective commitment effect significantly to OCB & 3,714 & Significant & Accepted \\
\hline $\begin{array}{l}\text { The identity of the influential organization } \\
\text { significantly to OCB }\end{array}$ & 4,447 & Significant & Accepted \\
\hline
\end{tabular}




\section{DISCUSSION}

The first hypothesis, influential Islamic work ethic significantly to affective commitment means that with the increasing practice of Islam's work ethic, it will improve the affective commitment of human resources to organizations. The results of this study in accordance with the results of the research of Yousef (2000) and Nizam et.al (2016).

The second hypothesis, the work ethic of influential Islamic Organization identity significantly to meaning with the rise of the practice work ethics of Islam then it will increase the Organization's identity. The results of this research prove the opinions delivered by Hatch and Schultz (2004); Dhalla (2007) in Himam (2012) stating that the values held by members of the organization can evolve as the identity of the organization that is to distinguish between one organization by another organization. In this study, these values are the work ethics of Islam.

The third hypothesis, influential Islamic work ethic was not significant and positive towards OCB means with the rising practice of Islam's work ethic, it will increase the OCB are insignificant or can be said there is no Islamic work ethic influences against the OCB. The results of this study in accordance with Alhyasat (2012) in terms of the dimensions of skill, responsibility, justice, cooperation has no effect significantly to OCB.

The fourth hypothesis, influential affective commitment significantly to OCB affective commitment with increasing means it will increase the OCB. The results of this study in accordance with the results of the research Subejo et.al (2013).

The fifth hypothesis, influential organization identity significantly to OCB meaning with the rise of the identity of the organization it will increase the OCB. The results of this study in accordance with the results of the research Amini et.al (2016).

\section{CONCLUSION}

Significant influential Islamic work ethic and affective commitment towards positive meaning with the rise of the application or of the practice work ethics of Islam then it would increase the commitment of affective HR against the organization. Significant influential Islamic work ethic and positive towards the identity of the organization that is to say with the increasing application of Islamic practice or work ethic, it will enhance the Organization's identity. Influential Islamic work ethic did not significantly to OCB.

Affective commitment of significant and positive effect toward OCB affective commitment with increasing means it will improve the behavior of OCB among HR. The identity of the Organization's significant and positive effect toward OCB meaning with the rise of the identity of the organization it will improve HR between OCB. 


\section{REFERENCES}

Abbasi, Abdus Sattar dan Aiza Hussain Rana (2012). "Impact of Islamic Work Ethics, Reward System and Organizational Environment on Citizenship Behavior of Employees”. Sci. Int.(Lahore).Vol.24.No.4. pp.513-519

Ahmad, Shukri dan Musa Yusuf Owoyemi (2012). "The Concept of Islamic Work Ethic: An Analysis of Some Salient Points in the Prophetic Tradition". International Journal of Business and Social Science. Vol.3.No.20

Alhyasat, K.M.K. (2012)."The role of Islamic work ethics in developing organizational citizenship behavior at the Jordanian Press Foundations." Journal of Islamic Marketing. Vol.3.No.2.pp.139-154

Ali, Abbas J. dan Abdullah Al-Owaihan (2008). "Islamic work ethic: a critical review". Cross Cultural Management: An International Journal. Vol. 15.No.1.pp. 5-19

Allameh, Sayyed Mohsen, Saeed Alinajimi, Ali Kazemi (2012). "The Effect of Self-concept and Organizational Identity on Organizational Citizenship Behavior (A Case Study in Social Security Organization of Isfahan city)". International Journal of Human Resource Studies. Vol.2.No.1

Amini, Mohsen, Mehdi Amini, Masoud Ghodsi, Mani Rafiee(2016). "Evaluation of Relationship between Social Self Concept, Organizational Identity and Organizational Citizenship Behavior". Asian Social Science. Vol.12.No.2

Fakhar, Hafiz Muhammad Zaman, Muhammad Yousuf Khan Marri, Arshad Mahmood Sadozai, Muhammad I. Ramay (2012). "Islamic Work Ethics in Contemporary era and its relationship with Organizational Citizenship Behavior (A study based on public sector hospitals and banks in Pakistan)". Interdisciplinary Journal of Contemporary Research in Business. Vol.4.No.6

Ferdinand,Augusty (2005) Structural Equation Modeling dalam Penelitian Manajemen, Badan Penerbit Universitas Diponegoro : Semarang

Ghozali, Imam (2017) Model Persamaan Struktural, Konsep dan Aplikasi dengan Program AMOS 24 Update Bayesian SEM, Edisi 7, Badan Penerbit Universitas Diponegoro : Semarang

Han, Sia Tjun, Agustinus Nugroho, Endo W. Kartika, Thomas S. Kaihatu (2012). “Komitmen Afektif dalam Organisasi yang Dipengaruhi Perceived Organizational Support dan Kepuasan Kerja”. Jurnal Manajemen dan Kewirausahaan.Vol.1.No.14

Harper, Pamela J. (2015). "Exploring forms of organizational citizenship behaviors (OCB): antecedents and outcomes". Journal of Management and Marketing Research. Vol.18- February 
Hidayat, Muchtar (2010). “Analisis Komitmen (Affective, Continuance dan Normative) Terhadap Kualitas Pelayanan Pengesahan STNK Kendaraan Bermotor (Studi Empiris pada Kantor Bersama Samsat di Propinsi Kalimantan Timur)”. Jurnal Manajemen dan Kewirausahaan. Vol.12.No.1.pp.11-23

Himam, Fathul (2012). "Identitas Organisasi: Eksplorasi terhadap Dimensi dan Maknanya Bagi Perubahan Organisasi”. Jurnal Siasat Bisnis.Vol.16.No. 2.Hal.198-204

Kusumastuti, Arviana Fitri dan Harlina Nurtjahjanti (2013). "Komitmen Afektif Organisasi Ditinjau dari Persepsi terhadap Kepemimpinan Transaksional pada Pekerja Pelaksana di Perusahaan Umum (Perum) X Semarang”. Jurnal Studi Manajemen dan Organisasi. Vol.10.No.1.Hal.13

Nizam, Shahrul bin Salahudin, Siti Sarah binti Baharuddin, Muhammad Safizal Abdullah, Abdullah Osman (2016). "The Effect of Islamic Work Ethics on Organizational Commitment".Procedia Economics and Finance. Vol.35.pp.582-590

Podsakoff, Philip M., Scott B. MacKenzie, Julie Beth Paine, Daniel G. Bachrach (2000). "Organizational Citizenship Behaviours : A Critical Review of The Theoretical and Empirical Literature and Suggestions for Future Research". Journal of Management. Vol.26.No.3.pp.513-563

Prasetyo, Yan Wahid dan Fathul Himam (2013). "Pengembangan Identitas Organisasi sebagai Strategi Bisnis”. Jurnal Psikologi. Vol.40.No.2.pp.226-239

Rhoades, L., Elsenberger, R., dan Armeli, S. (2001). “Affective Commitment to Organization : The Contribution of Perceived Organizational Support”. Journal of Applied Psychology.Vol.86.No.5.pp.825-836

Rodhiyatun, Edi Woeryanto, dan Tri Nur Hidayati (2014). "Persepsi Pasien tentang Hospitality terhadap Kepuasan di Ruang Rawat Inap Rumah Sakit Islam Kendal". Prosiding Konferensi Nasional II PPNI Jawa Tengah 2014.pp.292-297

Subejo; Eka Afnan Troena; Armanu Thoyib; Siti Aisjah (2013). "The Effect of Organizational Commitment and Organization Identity Strength to Citizenship Behaviour (OCB) Impact On Fire Department and Disaster Employee Performance in Jakarta Indonesia”. IOSR Journal of Business and Management (IOSR-JBM).Vol.10.Issue 3.pp.30-36

Wahyudi, Amin (2012). "Pengaruh Komitmen Organisasional dan Etika Kerja Islami terhadap Performansi Kerja Para Staf Pengajar pada Perguruan Tinggi di Surakarta dengan Basis Institusi sebagai Variabel Moderator”. Jurnal Muqtasid. Vo.3.No.1.pp.73-89

Yousef, Darwish A. (2000). "Organizational commitment as a mediator of the relationship between Islamic work ethic and attitudes toward organizational change.Human Relations.Vol.53.No.4.pp.513

Zahrah, Novia, Siti Norasyikin Abdul Hamid, Shamsul Huda Abdul Rani, Bidayatul Akmal Mustafa Kamil (2016). "Enhancing Job Performance through Islamic Religiosity and Islamic Work."

International Review of Management and Marketing. Vol 6 Special Issue (S7).pp.195-198 